\title{
Sustainable Case Study: United States Steel Corporation
}

Gayle Marco, Ph.D., Robert Morris University, USA

Steve Clinton, Ph.D., Robert Morris University, USA

Dean R. Manna, Ph.D., Robert Morris University, USA

Kiel Matisz (student), Robert Morris University, USA

\begin{abstract}
Overall, the North American Steel Industry has made significant strides to protect our environment and preserve our resources by: reducing overall energy consumption per ton of steel by 29\% since 1990; reducing greenhouse gas (GHG) emissions (including CO2) by more than 25\% from 1994 thru 2003; reducing air toxics volumes by more than 70\% from 1994 thru 2003, and total air \& water discharges by 69\%; collecting and reusing of steel making by products such as: slag for road building, railroad ballasts, fertilizer, glassmaking, \& other applications; coke oven \& steel making gases for fuel/heat generation; increased steel manufacturing efficiencies now result in the production of 100 units of steel from 114 units of raw steel vs. 140 units previously, which has resulted in a yield improvement of $16 \%$ to $87 \%$ from $71 \%$. These statistics indicate that the industry is doing an efficient job improving the environment in such a short span of time. Recently, United States Steel Corporation has been taking strides to improving sustainability within its corporation. Originally, U.S. Steel has always been a company that prides itself on good business practices. Today, they are taking further steps by incorporating sustainable measures to fit the trend developing in society. This is a study devoted to evaluating U.S. Steel's current successes and failures regarding their recent sustainability practices.
\end{abstract}

Keywords: Steel Industry; Sustainability; Energy Industry

\section{U.S. STEEL'S HISTORY}

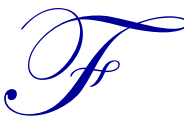

ounded in 1901, U.S. Steel started as an incredibly large company. Since its inception, U.S. Steel was formed from two companies, J.P. Morgan and Elbert Gary's company merged with Andrew Carnegie's company, which generated approximately $\$ 1.4$ billion in capital. During this time period, U.S. Steel was a major player in the steel industry controlling almost two- thirds of the American steel market through its production endeavors. Throughout the years, U.S. Steel did a great job to stay on top of the industry by acquiring other companies that could contribute in the industry. Some of the acquisitions included: American Steel \& Wire Co., National Tube Company, American Tin Plate Co., American Steel Hoop Co., and American Sheet Steel Co.

In the eighties, U.S. Steel began to use innovative measures to become a player in the global steel industry. A major contributor to this project was that U.S. Steel had to reduce its domestic raw steel production, which in turn led to U.S. Steel starting several international and domestic ventures and partnerships. In 1982 and 1986 the corporation became involved in the energy industry with its acquisition of Marathon Oil Company and Texas Oil \& Gas Corp. By the turn of the century, U.S. Steel had foreign partners in steel production plants in Europe and Canada. The company is also expanding domestically after purchasing assets from National Steel Corporation.

A new vision was eventually needed as U.S. Steel felt the need to improve sustainability measures and wanted to improve its geographical footprint. Because of this U.S. Steel had to split into two separate industries: U.S. Steel Corporation and Marathon Oil Corporation. The cause to this split was because the company was growing 
too large. ${ }^{3}$ U.S. Steel is one of the biggest competitors in the global industry, and is currently the biggest steel producer in the North America. Over hundred years later, U.S. Steel still remains to be the largest steel producer in the United States.

\section{U.S. Steel's Sustainability Mission}

U.S. Steel defines sustainability as meeting the needs of the present without compromising the ability to meet the needs of future generations. U.S. Steel focuses on providing value by evaluating their complete supply chain process to determine where operational efficiencies and cost reductions can be achieved. To distribute its steel, U.S. Steel uses different methods of transporting including, vessels, barges, railways and trucks. Also, U.S. Steel generally has a good analysis and development of pricing options for its product so that it would be the most efficient and cost-effective way for customers to receive product given their domestic transportation methods to save on cost. Finally, the company will fund continuing sustainability programs through constant research and development that will allow employees to expand on current environmental strategies. ${ }^{3}$

\section{U.S. Steel's Product Line}

Clearly, U.S. Steel Corporation produces steel, but they have a few variations of manufacturing steel. As a company, they segment their production into two different lines of steel production: Flat-rolled Steel and Tubular Steel. The Flat-rolled Steel can also be segmented into the six different markets where the product can be used. These markets include: Appliances, Automotive, Construction, Service Centers, Sheets and Tin.

As for the Appliances market, U.S. Steel is one of the main suppliers for steel products that make up household materials. U.S. Steel designs its product in the appliance industry to have porcelain-enamel coatings and prepainted sheet products. This allows U.S. Steel to have the competitive edge in this industry as retailers likely prefer a finished product. $^{3}$

When most people think of steel, there is a direct correlation to the automotive industry. Each industry can be a direct beneficiary to the other in the form of supply and demand. U.S. Steel specifically has a site located in Troy, Michigan close to the large manufacturers in the automotive industry in order to design and develop new improvements. This automotive lab allows for U.S. Steel to use its automotive technology in an efficient and timely manner.

Steel can be used in the construction industry. U.S. Steel construction products include metal building systems, roofing and siding components, doors, commercial and residential framing, truss plates and connectors, decking, bridge and highway products, culvert, central heating and air conditioning equipment, water heaters, retail shelving systems, and steel furniture. Like the automotive industry, U.S. Steel provides the needed furnishing for its steel products and it has plants near the major construction locations around the nation.

Recently, the sheet products have made improvements by adding new and improved equipment. There are many different types of sheet products, but essentially there is hot-rolled, cold-rolled and coated sheet. Many of the sheet products have improved because the new technology has allowed U.S. Steel to have a more chemically sound product. Another improvement that has improved the sheet product and that has been beneficial specifically to sheet steel is the technology to improve the thickness of the sheet output.

Tin mill products are the last product of Flat-rolled steel and these include: electrolytic tinplate, electrolytic chromium coated steel), tin coated steel, and black plate, an uncoated product. ${ }^{3}$ Tin is usually demanded by the container industry, which is the industry that provides tin cans as holders for beverages.

Shifting towards U.S. Steel's Tubular product, they basically produce two types of pipe. The pipes include: Seamless pipe in sizes of 2.063" to 26" in outside diameter or an Electric resistance welded pip in sizes 8.625" to 20 " in outside diameter. ${ }^{3}$ This product can be used for a number of applications, but many consumers are finding Tubular products good for drilling purposes. U.S. Steel products have been used to drill into the Marcellus Shale, a gaseous form of rock thousands of feet below the earth's surface. 
U.S. Steel has an innovative product line in which there have been many improvements and additions in the past. By U.S. Steel's definition, their product line is definitely sustainable because they do not only have products that meet the needs of the present, but they are leading they are leading the way for future steel manufacturers to make improvements to compete with their sustainable products.

\section{U.S. Steel's Sustainability Strategies: Reduce, Reuse, Recycle \& Restore}

The core of U.S. Steel's sustainability strategies is simply to reduce, reuse, recycle and restore. For U.S. Steel, all sustainability procedures can be traced back to the 4 R's and all types of sustainability procedures can be categorized under these sections. Below are some of the facts and statistics that fall under U.S. Steel's four categories:

\section{Reduce:}

- $\quad$ Energy accounts for about 20 percent of the total cost of making steel, and we are constantly searching for ways to reduce that number. ${ }^{3}$

- $\quad$ By implementing technological innovations and improved operating practices, U. S. Steel now uses 45 percent less energy per ton of steel shipped than we did in 1975 . $^{3}$

- $\quad$ Reducing greenhouse gases is also important, and in just over 10 years, the industry has reduced carbon emissions from 1,100 pounds per ton of raw steel to 880 pounds, a reduction of about 20 percent. $^{3}$

\section{Reuse:}

- $\quad$ Each year, industry blast furnaces generate 12 million tons of slag; basic oxygen furnaces generate six million tons; and electric arc furnaces, four million. Yet virtually all of the blast furnace slag and half of the basic oxygen and electric arc furnace are beneficially reused. ${ }^{3}$

\section{Recycle:}

- More than 70 million tons of scrap was recycled in 2002, resulting in an overall steel recycling rate of almost 71 percent. $^{3}$

- In addition to saving money and resources, recycling preserves landfills, offsets portions of municipal waste management costs, and provides an example for the recycling of other products. ${ }^{3}$

\section{Restore:}

- In partnership with potential buyers, U.S. restores brownfields to the level required for future industrial, commercial or residential use. ${ }^{3}$

- $\quad$ U. S. Steel has developed a number of brownfield sites over the years, including the Waterfront shopping district on the site of the former Homestead Works near

Pittsburgh, Pa., and the industrial park adjacent to our Fairless Plant near Philadelphia, $\mathrm{Pa}^{3}$

These are just a few points where U.S. Steel has done an exceptional job performing towards their environmental stewardship measures. U.S. Steel will continue to make future improvements in these four categories for years to come because much of the 4 R's are based off of performance measures in previous years. As a corporate entity, it is important to track and value success as a company from measures in previous years. In turn, this allows a corporation like U.S. Steel to measure whether they are moving their sustainable practices like the 4 $\mathrm{R}$ 's in the right direction.

\section{U.S. Steel's Employees}

At U.S. Steel, there has always been a purpose to strive to be an industry-leading safety program long before the Occupational Safety and Health Act (OSHA) and the Mine Safety and Health Act (MSHA) were passed. ${ }^{3}$ 
U.S. Steel continues to develop a safety program for all its 50,000 employees. All employees must follow rules and procedures in order to work safely. These rules are mainly rules of good business practice, but can indirectly affect sustainability. These rules are: wear all required personal protective equipment at all times, keep our workplaces clean and free of hazards, keep our workplaces free of alcohol and illegal drugs as well as the effects of their use, including the inappropriate use of prescription drugs, obtain immediate medical attention for all injuries, immediately report to our supervisors all injuries, incidents, illnesses and unsafe conditions. ${ }^{3}$

This program rejects the notion that "accidents just happen" and reaffirms the guiding principles that "all incidents and injuries can be prevented" and "safety is a personal responsibility." ${ }^{3}$ This program can be indirectly considered sustainable because it allows people to continue to work in a safer environment. U.S. Steel prides itself on its safety and has made achievements to show.

All drivers must be equipped with appropriate Personal Protection Equipment, including hard hats, safety glasses, hard soled shoes, long sleeved shirts, and pants. All drivers must have documented training in cargo securement in accordance with the Code of Federal Regulations, 49 CFR 393.100. All drivers must have industrial environment safety training. ${ }^{3}$

It is important to stress that there are many employees that have many different working functions in their respective jobs. More importantly, all the employees have to be unified in their safety practices as all employees work in a unified group under the U.S. Steel roof.

\section{U.S. STEEL CERTIFICATION}

Many of U.S. Steel's products and facilities follow the certifications and regulations of the steel industry. Traditionally, the company has always maintained three standards as a baseline for sustainable measures. The three certifications that U.S. Steel has earned are ISO 14001, ISO 9001 and Lab accreditation which deals with environmental and quality procedures in the plants; both of these measures are linked to sustainability programs.

- $\quad$ ISO 14001 - provides a framework for achieving more consistent and reliable environmental management. It can also be used as an indicator of a company's desire and commitment to foster environmental protection. $^{3}$

- $\quad$ ISO 9001 and ISO/TS 16949 emphasize the measurement of customer satisfaction, process management utilization, and information analysis to drive continuous improvement. ${ }^{3}$

- Lab accreditation shows a lab is capable of being consistent in calibrations and able to increase efficiency by following specific procedures time after time for clients. ${ }^{3}$

These certifications recognize U.S. Steel's achievements in sustainability domestically and internationally. Many of the U.S. Steel factories have these accreditations and standards which proves U.S. Steel's commitment to sustainability.

As well, U.S. Steel has maintained both a LEED certified standard and an Energy Star standard which is a relatively new trend within the United States. U.S. Steel is leading the charge in these aspects because steel as a product has been demonstrated to be one of the most recycled products today. U.S. Steel is trying to continue to promote that they are moving toward the green building movement and focusing its efforts on recycling and durability of steel. U.S. Steel has received an Energy Star award for heat and power, specifically given to Gary works. Another notable achievement was that U.S. Steel has received the Pennsylvania Governor's Award for Environmental Excellence. Currently, U.S. Steel is an older company with a lot of steel mills around the world. Therefore, it has been a struggle for U.S. Steel to achieve these LEED certified buildings because most of their buildings are eighty to hundred years old. One noteworthy U.S. Steel building is the Research and Technology Center in Munhall, Pa. This building has achieved as Silver standard LEED certification by using innovative ways to conserve water and recycle materials properly. 


\section{Energy Consumption and Emissions}

U. S. Steel is making meaningful strides in reducing energy consumption and greenhouse gas emissions. These actions are driven by both the need to manage the high cost of natural gas and coal, as well as the need to protect our natural surroundings and watchdog companies do their best to set standards for the industry. U.S. Steel's Gary Works facility was evaluated by U.S. Department of Energy and praised the company for being involved in the lowest energy intensity per ton of steel produced compared to steelmaking in other nations. ${ }^{3}$ Energy intensity or primary energy per ton of steel produced is significantly lower due to carbon dioxide emissions that have fallen 55 percent during that time to 1 metric ton per ton of steel produced. ${ }^{3}$ U.S. Steel prides itself on having one of the cleanest steel production systems around the world.

\section{METHODS OF TRANSPORTATION}

The only method of transportation that seemed not to be used was air transportation. Each year there are approximately, 800,000 trucks, 77,000 railcars, and 220 barge loads. $^{3}$ There are some safety and environment friendly regulations that the drivers of the transportation methods used to ship the product to the customer must follow in U.S. Steel. The main reasons air transportations was not used is obviously the product U.S. Steel sells is steel and it is such a heavy product to ship and with a plane there is very limited space where the product can be stored. It would be far too expensive and not economically worth it to ship steel in the air.

An example of U.S. Steel's sustainability measures are they have reduced the impact of traffic associated with a large portion of construction material from within the Gary Works site and laying out transportation routes with minimal effect on neighborhoods. All off-site deliveries associated with the project will be made during daylight hours.

\section{TRANSACTION SERVICES}

For a number of years, U.S. Steel has made it possible for consumers to order steel over the internet. U.S. Steel has become much more efficient with its online retail service and this acts as an online retailing tool that has increased production rates and competitive sustainability in the metals industry. Most importantly, this allows customers to interact directly with U.S. Steel's sales and production departments instead of going through a drawn out process of technicalities. The two web pages that U.S. Steel employs for retail transactions are SteelTrack and Microsite. As for SteelTrack, it is an Electronic Data Interchange system that US Steel pioneered for retailing transactions. It allows for transactions including advanced shipping notices, material releases and invoices, but it also provides the customer on crucial data, order status, inventory tracking, shipment history, physical and chemical test reports.

As for U.S. Steel's purchases, they look for materials that will help to improve their performance. Equipment purchases that improve energy efficiency are very important, but in recent years because of the economic downturn their capital spending has been cut. In 2009, U.S. Steel cut a large majority of the capital spending plan, including energy efficiency improvement efforts.

\section{U.S. STEEL GOVERNMENT REGULATION}

There are many government regulations in the steel industry that have an impact on trade and sustainability. Because steel is produced in large quantities internationally, the U.S. government has placed tariffs on importing steel. A tariff increased the price of importing steel by a larger margin and therefore directly impacts U.S. Steel's production and shipping of steel based on exchange policies. These tariffs have the ability to harm the steel industries profit.

The government has constantly put pressure on improving U.S. Steel's manufacturing plants to become more environmentally friendly. U.S. Steel has to improve its standards via LEED certifications or Energy Star programs given by the Environmental Protection Agency. Operating within environmental standards increases operating costs for U.S. Steel in the short term, but in the long run the company will be able to operate more 
efficiently. Therefore, the government regulation has the potential to severely alter the company's profit. EPA worked with the Steel Manufacturers Association on a program of training and technical resources to help steelmakers implement environmental management systems. ${ }^{1}$ SMA members produce steel by melting scrap metal and other iron-bearing materials in electric arc furnaces. These steel mini-mills produce more than half of all new U.S. steel, mostly by recycling scrap steel. The comprehensive environmental management approach taken with an EMS provides a sound framework for pursuing improved environmental performance. ${ }^{1}$

\section{U.S. Steel In Relation To Competitors}

In the global marketplace, there are many steel producers. In fact, there are forty-nine companies that produce at least 3 million tons of crude steel. ${ }^{4}$ As of 2009, U.S. Steel was the eleventh largest steel producer in the world, but more importantly U.S. Steel is still the largest North American steel producer.

In the past, U.S. Steel was a global leader in steel production. In 1970, U.S. Steel ranked second as the most abundant steel producer in the world with twenty eight million metric tons produced. They remained in this position for 15 years until 1985 where there began to be many international competitors entering the steel industry. At that point, U.S. Steel had dropped to a position approximately where it sits today, still near the top 10 and most importantly still produces the majority of North American steel.

Currently, the largest North American steel producer, Nucor, is not far behind U.S. Steel's production output of 15.2 million tons. ${ }^{4}$ Nucor is a corporation based out of Charlotte, North Carolina and currently produces 14 million tons of crude steel. ${ }^{4}$ This company prides itself on using mini-mills as production centers and generating steel using electric arc furnaces. Nucor's innovative ways of steel production and their corporate strategy has helped to gain a competitive advantage.

Internationally, U.S. Steel is a smaller player among steel producers. The four major players in steel production are: Arcelor Mittal, Baosteel, Nippon Steel and JFE Holdings. Arcelor Mittal is a European company based in Luxembourg and produces far more steel than any other company at 77 million tons. ${ }^{4}$ Arcelor Mittal can also be consider a domestic competitor in a sense because they have production facilities throughout North America that compete with U.S. Steel. Next, Baosteel is China's largest producer of steel and JFE holdings is Japan's largest producer of steel. Respectively, these two companies produce double of the amount the steel that U.S. Steel did in 2009, each producing around 30 million tons. ${ }^{4}$ Lastly, Nippon Steel has been a head-to-head competitor since the 1970 when they were ranked first in steel production. Now, they sit fourth among all steel producers and have effectively continued to produce large quantities of steel.

In regards to environmental stewardship or sustainability, all of these companies have made it a priority to practice such standards. All the companies want to show their consumers that they are taking strides towards social responsibility. Comparatively, U.S. Steel has done a more thorough job reducing emissions. For instance, U.S. Steel has reduced greenhouse gas emissions by 33 percent by 1990, whereas Nippon Steel Corporation as only reduced emissions by 9.8 percent. ${ }^{4}$ U.S. Steel is a leader in sustainability amongst its competitors, but it is important to note all companies are improving. Clearly, this is a contributing factor as to why steel is the more recycled material in the world.

\section{U.S. Steel and the Community}

Community relations are an important aspect that U.S. Steel tries to pride itself on. Continued partnerships to protect and preserve natural resources will help show efforts U.S. Steel is making to restore. These partnerships allow U. S. Steel, other manufacturers, government agencies, and community and environmental stakeholders to maximize their resources to make significant impacts on our communities. Looking to continuously update and introduce new state-of-the-art technology to become more efficient with methods of helping to restore brownfields.

An example of U.S. Steel's partnership in this community improvement project is that U.S. Steel combined forces with the Resource Conservation and Recovery Act. This allowed U.S. Steel to find a corrective action plan with all the materials that U.S. Steel was wasting. This partnership dealt with the improvement of sewer systems and promoted the usage of solid waste management areas. 
U. S. Steel has also actively partnered with the U.S. Department of Energy and the U.S. Environmental Protection Agency to promote energy efficiency and environmental stewardship. These partnerships have resulted in energy assessments performed by the Department of Energy that resulted in more than $\$ 65$ million in cost savings for the company and a reduction in $\mathrm{CO}_{2}$ production.

\section{U.S. STEEL'S FUTURE PLANS}

Moving forward, U.S. Steel is striving to continue growing to become a sustainable leader in the steel industry. As a corporation, they believe that in order to achieve their goal they will need to develop an innovative macroeconomic plan for the future. Looking to continuously update and introduce new technologies that will help to introduce sustainable measures will help U.S. Steel remain competitive. As well, U.S. Steel needs to be constantly thinking about reducing energy inefficiency in this industry. This will only be achieved if there is continuous research and development to improve product sustainability. They are trying to improve environmental safety for their employees that will correlate into improved business practices for the corporation. These procedures will help to guide U.S. Steel down a path towards improving sustainability.

\section{AUTHORS INFORMATION}

Dr. Gayle J. Marco received her Ph.D. degree from the University of Pittsburgh. (Major: Marketing Education and Vocational Education) Her research interests include various areas of consumer decision making, buyer behavior and the various areas of sustainability. She has consulted for numerous companies in the Pittsburgh area. The consulting areas include product repositioning, market development for new products, needs assessments, and market plan development. Professor Marco integrates "real" marketing projects for area businesses in her teaching at the undergraduate and graduate level. She has published in the Journal of Global Business, The Journal of American Academy of Business, American Journal of Business Education, and Journal of Business Case Studies as well as numerous conference proceedings. E-mail: $\underline{\text { marco@rmu.edu }}$

Dr. Steven R. Clinton received his Ph.D. degree (Major: Marketing; Minor: Logistics) from Michigan State University in 1998. His research interests include international supply chain organization, customer service in logistics, logistics strategy, and selection processes involving international logistics service intermediaries. Steve is an Associate Professor of Marketing at Robert Morris University. He has published in Journal of Business Logistics, Transportation Journal, International Journal of Physical Distribution and Logistics Management, Journal of Production and Inventory Management, and International Marketing Review as well as numerous conference proceedings. E-mail: $\underline{\text { Clinton@rmu.edu }}$

Dr. Dean Manna has consulted and conducted training seminars for twenty-five years in the areas of Emotional Intelligence related to professional selling and management. Dr. Manna utilizes a pragmatic yet highly motivational and entertaining approach in his classroom instruction and seminars, while transmitting valuable information. He has published a complete instructional manual on Client Centered Selling for use in the classroom and corporate training. His teaching specialty is in the area of Professional Selling and Emotional Intelligence, both at the undergraduate and graduate level. Dr. Manna's primary research interest is on Emotional Intelligence and its effects on productivity and morale in the public and private sector. He has made several presentations at various national and international conferences. He also has over twenty publications in various academic journals. Dr. Manna was a past president of the Pittsburgh Chapter of the American Marketing Association. He holds his undergraduate degree in Business from Gannon University, an MBA from the University of Cincinnati, and his Ph.D. from the University of Pittsburgh. He is a University Professor of Marketing and Department Head of the Marketing Department in the School of Business at Robert Morris University. E-mail: Manna@ @rmu.edu (Corresponding author)

Kiel Matisz is currently a Junior at Robert Morris University, where he is a Bachelor of Science in Business Administration with concentrations in Economics and Marketing. At RMU, Kiel is involved in student engagement groups such as Phi Beta Lambda and the Colonial Leadership Academy. He is also a Captain on RMU's Men's Lacrosse Team while still maintaining a 3.73 GPA. This past year Kiel rose over $\$ 700$ for Prostate Cancer with the Headstrong Foundation and tries to actively participate as an outstanding member of the RMU community. Recently, Kiel has taken an interest in studying sustainability and environmental aspects of the economy. E-mail: kymst11@mail.rmu.edu 


\section{REFERENCES}

1. Environment Protection Agency. (2011). Iron and Steel. Retrieved from http://www.epa.gov/sectors/sectorinfo/sectorprofiles/steel.html

2. Steel Recycling Institute. (2011). Goal: Steel, Our Most Sustainable Material. Retrieved from http://www.recycle-steel.org/Sustainability.aspx

3. United States Steel. (2011). Environmental Stewardship. Retrieved from http://www.uss.com/corp/environment/overview.asp

4. World Steel Association. (2010). Worldsteel Member Companies 2009 Crude Steel Production, Over 3 Million Tons. Retrieved from 1.org/pictures/programfiles/Topsteelproducers[1].pdf 